\title{
MISSION IN THE BOOK OF ACTS: MISSION OF THE CHURCH ${ }^{1}$
}

\author{
Christoph Stenschke \\ Forum Wiedenest, Bergneustadt, Germany \\ New Testament \\ University of South Africa
}

\begin{abstract}
This paper examines how the early Christian mission is portrayed in the Book of Acts. While leading figures such as Peter and Paul and their ministries dominate the narrative, there is a substantial amount of evidence that many more people than the apostles were involved in spreading the Gospel under different, at times adverse, circumstances. Even the mission activities of prominent figures are deeply embedded in the mission of various churches, above all the church in Jerusalem. This inspiring portrait challenges some contemporary notions of mission and evangelism. While mission is primarily the mission of God (missio Dei), it is also the mission of the church (missio ecclesiae) - not only of its ordained ministry or particular societies devoted to mission, but the mission of all Christians so that many more Africans may go on their way rejoicing (Acts 8:39).
\end{abstract}

Key Words: The Book of Acts, Mission in the New Testament, Mission of the Church, Early Christianity, Paul, the Apostle, Paul's Portrait in Acts

\section{Introduction}

People associate and perhaps even equate Paul the apostle with early Christian mission. After all, he was the early Christian missionary par excellence. One of the reasons for this is the prominent place he occupies in the Book of Acts, which is the only canonical account of the spread of early Christianity. His ministry is described in more detail than that of any other early Christian missionary. If Paul's theology was more often understood as mission theology (as it should be!), ${ }^{2}$ Paul would be seen even more clearly as the greatest of all missionaries. The purpose of this article is not to diminish the significance of Paul the missionary - instead, I shall attempt to show that Paul's mission cannot be separated from the church.

My concern in this article is to understand the mission of Paul as the mission of the church. ${ }^{3}$ In Acts, the church's mission was well advanced before Paul appeared on the scene. In other words, as far as mission is concerned, more is involved than Paul and his activities. What evidence is there for the spread of the gospel by other Christians, be they

\footnotetext{
This article is based on a lecture presented at the conference The Book of Acts and the Missional Church, held at Stellenbosch University, South Africa in May 2009.

2 For Paul's theology as a theology of mission see IH Marshall, New Testament Theology: Many Witnesses, One Gospel (Downers Grove; Leicester: InterVarsity Press, 2004), (34-37): "New Testament theology is essentially missionary theology... A recognition of this missionary character of the documents will help us to see them in true perspective and to interpret them in the light of their intention ...”; cf. also pp. $709 f$.

3 The question whether the mission of Paul, his co-workers and his churches were representative, or the exception, is disputed in recent scholarship.
} 
the apostles or ordinary Christians, in their own places of residence and spheres of influence? How were they involved in the spread of the gospel elsewhere? ${ }^{4}$

We begin with the mission of the church of Jerusalem. Then we survey the mission of the Hellenists in Acts 8-11 as an extension of the mission from Jerusalem. Most of this article concerns the mission of the Antiochene church through Barnabas, Paul, John Mark and Silas. Finally, I shall briefly consider the mission of other churches in Acts and draw certain conclusions.

\section{The Mission of the Church in the Book of Acts}

For historical and literary reasons, we shall follow the narrative sequence of Acts. This procedure will also show that mission in Acts is the mission of the church and of individual churches.

Before engaging the text, we need to consider briefly the purpose and emphasis of Acts. Acts does not intend to provide a comprehensive history or assessment of the ministry of all the apostles of the church in Jerusalem, or of all other Christians, or of all other churches. Even its presentation of Peter and Paul is selective. Acts was written with a different purpose in mind: it sketches the course of the gospel to the Gentiles and presents a broad apology for Paul's Gentile mission, with its claim that Gentiles can participate as Gentiles in God's salvation. In short, Gentiles do not have to become Jews first.

A detailed description of the role which different people and churches had in the spread of the gospel is therefore not to be expected. Neither the speeches at the so-called apostolic council (Acts 15:7-21) nor Paul's address to the Ephesian elders of Acts 20:18-35 - the only speeches in Acts that are directed to Christian audiences - contain direct challenges to actively spread the gospel. ${ }^{5}$ Nevertheless, Acts does directly or incidentally indicate that mission and church belong together.

\section{Mission of the Church in Jerusalem \\ - Mission in Jerusalem and beyond}

After Pentecost, the apostles began to proclaim the gospel in Jerusalem. Luke summarises the mission speeches of Peter (and of other apostles; see 4:2f) in chapters 2-4, through which many people came to faith in Jesus. ${ }^{6}$ In addition to these speeches and the reports of their result, Luke says of all the apostles: "And every day, in the temple and from house to house they did not cease teaching and preaching Jesus as the Christ” (5:42; although Luke only reports the speeches of Peter). They were charged by their opponents with "filling

4 For definitions of mission, see EJ Schnabel, Early Christian Mission I: Jesus and the Twelve (Downers Grove: IVP; Leicester: Apollos, 2004), 10-12 and Schnabel's recent Paul, the Missionary: Realities, Strategies and Methods (Nottingham: IVP/Apollos, 2008).

5 In addition, Luke's 'summary pieces' in Acts 2:41-47; 4:32-35; 5:12-16; 6:7; 9:31; 12:24; $16: 5$ and $19: 20$ also contribute to the Lukan portrayal of the spread of the gospel. They emphasise the work of God in this process and relegate the human protagonists into the background. For Luke's emphasis on the activity of God in the conversion of Gentiles see also C Stenschke, Luke's Portrait of Gentiles Prior to Their Coming to Faith, WUNT II.108 (Tübingen: Mohr Siebeck, 1999), 276-303. In these summaries the portrayal of the church/churches is also significant; see U Wendel, Gemeinde in Kraft: Das Gemeindeverständnis in den Summarien der Apostelgeschichte, NThD 20 (Neukirchen-Vluyn: Neukirchener, 1998), in particular pp. 170-80, 245-56.

6 For the high numbers of converts in Acts see C Stenschke, “Zu den Zahlenangaben in Apostelgeschichte 2 und 4, den Orten der Zusammenkünfte der Urgemeinde und ihrem materiellen Auskommen”, JET 20, 2006, 177-83. 
Jerusalem with their teaching” (5:17-28). The resistance of the Jerusalem religious leaders was - to start with - focused on the apostles; other Christians were not yet targeted.

The mission activities of the 120 followers of Jesus who had come with him from Galilee (1:15), of the relatives of Jesus (who now appear among the followers of Jesus in $1: 14)$ and of the large numbers of people who had come to faith $(2: 41 ; 4: 4)$ in Jerusalem or elsewhere are not mentioned. Many of them were probably involved, but Luke's focus is on the apostles as the representatives of Israel re-gathered and restored. R Gehring has also pointed to the significance of Christian houses, not only as Christian meeting places, but also for the spread of the gospel in Jerusalem. In addition to the apostles, many others will have been active in Jerusalem.

In addition to the inhabitants of Jerusalem, many pilgrims from all of Judea and the Diaspora were in the city for Pentecost. The countries, regions and cities from which they will have come are listed in Acts 2:9-11. The estimates of the numbers of pilgrims to these feasts differ widely. A fair guess would be about 100000 inhabitants of the city and, in addition, up to $150000-200000$ pilgrims. $^{8}$

Presumably, some of these pilgrims were among those who had become Christians. Many would have been in the city since Passover and were well acquainted with recent events (see Luke 24:18: "Are you the only visitor to Jerusalem who does not know the things that have happened there in these days?”). Many of them (again, presumably) stayed behind after the feast was over and participated in the life and ministry of the church: "And they devoted themselves to the apostles' teaching and the fellowship, to the breaking of bread and the prayers" (2:42; see also 2:43-47). ${ }^{9}$ After receiving the apostles' teaching and the fellowship of the church, many of these Christian pilgrims would have returned to their former places of residence, while others might have gone elsewhere. We do not know whether and how they were possibly prepared for mission during their stay in Jerusalem.

Some of the churches appearing later in Acts might have had their origin in the witness of these pilgrims. ${ }^{10}$ Damascus, 9:2; Judea, Galilee, Samaria, 9:31; Lydda, 9:32; Joppa, 9:36; Tyre, 21:3; Ptolemais, 21:8; Caesarea, 21:8-14. Acts 2:9-11 mentions pilgrims from some of these places in Jerusalem (e.g. from Rome). Paul was met by Christians in Puteoli, and was welcomed by Christians from Rome (28:13-15). Neither Acts nor the Epistle to the Romans indicates that the churches of Rome had been founded by apostles. Were these churches started by pilgrims returning from Jerusalem? In that sense the Christian mission may have started as the mission of pilgrims. Through them, the gospel went forth from Jerusalem.

House Church and Mission: The Importance of Household Structures in Early Christianity (Peabody: Hendrickson, 2004); compare e.g. 2:46; 4:23; 5:42; 12:12-17.

$8 \quad$ Stenschke, 'Zu den Zahlenangaben' contains a survey of research and discusses reasons for the high numbers.

9 The high number of pilgrims that remained behind in Jerusalem (for a longer period of time?) probably caused the community of goods in the church in Jerusalem; see B Capper, "The Palestinian Cultural Context of Earliest Christian Community of Goods”, in R Bauckham (ed.), The Book of Acts in Its Palestinian Setting, AFCS 4 (Grand Rapids: Eerdmans; Carlisle: Paternoster, 1995), 323-56.

10 The different places of residence of Aquila and Priscilla testify to the significant local mobility of many Diaspora Jews. Aquila came from Pontus, a region between Bithynia and Armenia towards the Northern coast of Asia Minor. He and his wife arrived in Corinth after they were expelled from Rome through an imperial edict in 49 AD (Acts 18:2f). Later the couple stayed behind in Ephesus (Acts 18:19; see also 1 Cor 16:19). According to Romans 16:3, they returned to Rome after the death of Claudius in autumn 54. 2 Timothy 4:19 locates them (presumably at a later point in time) back in Ephesus; cf. the detailed treatment in C Stenschke, "Married Women and the Spread of Early Christianity", Neot. 43, 2009, 145-94. 
Mission by Jewish pilgrims would not be restricted to those present at the first Christian Pentecost. The annual feasts of Judaism regularly brought large numbers of pilgrims to Jerusalem (see Acts 21:27-29). Following early Jewish precedents, it is likely that the church in Jerusalem had them in view and shared the gospel with them (see, however, Acts 8:26-39!). In addition to pilgrimages, Jews in considerable numbers also came to Jerusalem for other reasons (e.g. temple worship and service, delivery of alms, other religious duties, commerce, politics, education, to see relatives; see Acts 24:17: “After several years I came to bring alms to my nation and to present offerings”; see below for Paul's regular visits to the city).

The gospels report several encounters between Jesus and his disciples in Galilee in the period between the resurrection and ascension (Matt 28:16-20; John 21). Is it possible that some of the apostles or other Galilean Christians (see Luke 10:1-20; Acts 1:15) returned to Galilee for some time (cf. Luke 24:13) in order to proclaim the gospel there and/or to gather together the pre-Easter followers of Jesus there and elsewhere? The charge of Jesus to the disciples to remain in Jerusalem was temporarily limited to the coming of the Holy Spirit (1:4). It was not a matter of principle. Do the churches of all of Judea and Galilee and Samaria mentioned in Acts 9:31 derive from such activities (i.e. of the apostles and others)? Peter's visits to Lydda and Joppa (9:32-43) also suggests that the apostles felt some responsibility for Christians outside of Jerusalem.

The astonishing miracles of Peter (and other miracles) brought people "from the towns around Jerusalem" (i.e. the Judea of 1:8) to the city, "bringing the sick and those afflicted with unclean spirits" (5:16; in parallel to the ministry of Jesus). People from outside of Jerusalem benefited from the apostles' ministry and, presumably, also heard the gospel and spread it further on their return home (cf. Luke 8:38f; John 4:39-42).

The ministry of Stephen, a Jewish Christian with a Diaspora background and appointed to serve at the tables (6:1-6), indicates in passing that the number of those performing signs and wonders and proclaiming the gospel went beyond the circle of the apostles: "And Stephen, full of grace and power, was doing great wonders and signs among the people ... they could not withstand the wisdom and the Spirit with which he was speaking" (6:8-10; see also v. 13f). ${ }^{11}$ The longest speech of Acts is Stephen's apology, which arose from his proclamation and its alleged consequences for the Law and the temple (hence the charge against Stephen by false witnesses!, 6:11-14). The speech is indirectly missionary in nature. Luke's substantial section on Stephen is noteworthy because, apart from Peter and John, the other apostles do not play a significant role in Acts (cf. 2:43f; 4:12, 17-21, 25, 27-32). ${ }^{12}$ Thus not only the apostles, but also other Christians in Jerusalem proclaimed the gospel. They seem to have done so in a way and with a measure of success that was similar to that of the apostles. ${ }^{13}$

The church of Jerusalem had other churches and the mission work of its members in view and identified with it (although some in the church viewed other churches from a critical stance):

11 Stephen follows the pattern of 'miracles-followed-by-proclamation' that appears in the ministry of the apostles in Acts $2 \mathrm{f}$.

12 For the missionary activities of the other apostles, see their names in the index in Schnabel, Early Christian Mission II: Paul and the Early Church (Downers Grove: IVP; Leicester: Apollos, 2004), 1826-44.

13 The spread of the gospel outside of Jerusalem does not begin with the apostles, but through Philip, who also belonged to the church of Jerusalem (6:3 'pick out from among you'; 6.5); compare, however, Acts 8:25. Stephen's special qualification (6:5) is not mentioned in connection with Philip. The systematic Gentile mission in Antioch was likewise initiated and sustained by people from the church in Jerusalem (see below). 
- Peter and John were sent to Samaria (8:14: "Now when the apostles at Jerusalem heard that Samaria had received the word of God, they sent ...”). They endorsed and supported the mission of Philip and proclaimed the gospel in many villages of the Samaritans on their way back (8:25). What happened elsewhere became known in Jerusalem and was of interest and concern there.

- Later Peter (and presumably others with him or on their own) "went here and there among them all” (9:32), namely the church throughout all Judea and Galilee and Samaria (9:31).

- Peter's mission to the house of Cornelius was embedded in the church contexts of Jerusalem and Joppa: in the beginning Peter stayed with the Christians in Joppa for many days, living in the house of Simon the tanner (9:43). Some of the Christians from Joppa (10:23) accompanied him to Caesarea. These "believers from among the circumcised who had come with Peter” (10:45) heard the Gentiles speak in tongues and baptised them.

- The events in Caesarea became known to the Christians (only to the Christians?): "Now the apostles and brothers who were throughout Judea heard that the Gentiles had also received the word of God” (11:1). The apostles, the church in Jerusalem and in all of Judea heard of these events and, to some extent, participated in the mission of Peter and the Christians from Joppa.

Owing to this commitment, Peter was summoned on his return to Jerusalem to give an account to some of them ("the circumcision party who criticised him", 11:3f) concerning the consequences of this step for his own ritual purity (11:1-18; v.3: "You went to uncircumcised men and ate with them"). The fact of proclamation to the Gentiles and of their conversion as such was apparently not questioned! Does this suggest previous incidents of Gentile mission? From Peter's account, the critics concluded that God had also granted the repentance that leads to life to the Gentiles (11:18).

- When the mission of the Hellenists in Antioch became known, Barnabas was sent from Jerusalem to Antioch. He saw the grace of God at work in the mission there. Later he went to Tarsus to bring Saul to Antioch (11:22-26) - Saul had also been a member of the church in Jerusalem (if only for a limited period of time; 9:26-30). The year-long stay of Barnabas in Antioch shows the sympathy and commitment of the Jerusalem church to the nascent Gentile mission. ${ }^{14}$

All of this suggests a lively participation and concern on the part of the church in Jerusalem.

\section{- Mission by the Hellenists of Jerusalem}

Luke describes in more detail the mission of other Jewish Christians of Jerusalem, namely, the Hellenists of the Diaspora. Their mission is also to be seen as the mission of the church in Jerusalem. We saw that Stephen (and presumably others) had proclaimed the gospel in Jerusalem and was challenged by members of the Diaspora synagogues (6:8-10). Their involvement outside Jerusalem began after the death of Stephen: "And there arose on that

14 The Antiochene church as a whole seems to have supported the mission activities of its members. The scruples that some Christians of Jerusalem harboured against Paul's 'law-free' Gentile mission (Gentiles first have to become Jews in order to participate in God's salvation; see Acts 15:1) apparently played no role in Antioch. 
day a great persecution against the church in Jerusalem, and they all were scattered throughout the regions of Judea and Samaria, except the apostles” (8:1) who, apparently, were able to stay behind in the city. The scattered Hellenists went about preaching the word (8:4). Through their ministry (in addition to the abovementioned possibilities) some of the churches mentioned later in Acts will have come into being (9:31, 36-41). According to Acts, these churches did not come into being through the ministry of the apostles, but through other members of the Jerusalem church, or through the churches which they had founded. ${ }^{15}$ Out of the - presumably extensive - mission activities of the Hellenist men and women (8:3?), certain episodes are reported in some detail:

1. Philip, also called to serve at tables (6:2-6), went about preaching the word in Samaria and later to an Ethiopian court official - both times with great success (8:4-39) and, in the case of Samaria, with the explicit approval of the apostles/church of Jerusalem (8:14-25). Taking his departure from Ashdod, Philip later preached Northwards, along the coast: "and as he passed through he preached the gospel to all the towns until he came to Caesarea" (8:40), where he re-appears in Acts 21:8-15. Philip is the first person mentioned in Acts who proclaimed the gospel outside of Jerusalem and who crossed not only geographic boundaries in doing so.

2. Saul of Tarsus set out to persecute Christians in Damascus (9:2). While we do not know when and by whom this church was founded, ${ }^{16}$ its existence indicates that some form of mission must have started from Jerusalem, although perhaps not as deliberate efforts as later mentioned for the church in Antioch! The Christians there knew of Saul and he had heard of them in Jerusalem.

Following his calling Saul became part of the church in Damascus ("he was with the disciples"), proclaimed Jesus in the synagogues saying "He is the Son of God" and increased more in strength and confounded the Jews by proving that Jesus was the Christ” (9:20-22). When Saul had to leave the city, his disciples assisted him (9:25). ${ }^{17}$ This possessive pronoun suggests that, through Saul's ministry, people had come to faith and that they (and presumably other Christians!) supported his ministry there, and were not just involved in his escape. Luke's purpose does not include a description of the origin, life and the missionary involvement of the church in Damascus.

On his return Saul was fully accepted - after some initial hesitation - by the Christians in Jerusalem ("So he went in and out among them at Jerusalem", 9:28) and "preached boldly in the name of the Lord". This proclamation happened at some point in time when the apostles were still in Jerusalem (cf. Gal 1:18). Paul's ministry was embedded in the church. ${ }^{18}$ It is noteworthy that, in the first three places where Luke mentions the mission activities of Paul (in Damascus, Jerusalem and Antioch - see

15 B Witherington, The Acts of the Apostles: A Socio-Rhetorical Commentary (Carlisle: Paternoster; Grand Rapids, Cambridge UK: Eerdmans, 1998), 301.

16 The intentions of Paul to persecute the Christians ("to bind all who call on your name", 9:14), the disciple Ananias (9:10) and Paul's immediate allegiance to the Christians there (9:19) presuppose that the gospel had arrived in Damascus by then. The Christians there could be linked to Jewish pilgrims and other visitors who had returned as Christians from Jerusalem or Judea or they might have come to faith through the ministry of the Hellenists who fled from Jerusalem $(8: 1,4)$. Were the activities of Paul the Diaspora Jew directed against dispersed Hellenists of Jerusalem and thus suggest the latter?

17 For discussion of textual variants and possible interpretations see CK Barrett, A Critical and Exegetical Commentary on the Acts of the Apostles I: Preliminary Introduction and Commentary on Acts I-XIV, ICC (Edinburgh: T \& T Clark, 1994), 466f.

18 Compare also IH Marshall, “Luke’s Portrait of the Pauline Mission”, in PG Bolt, M Thompson (eds.), The Gospel to the Nations: Perspectives on Paul's Mission. FS PT O’Brien (Leicester: IVP, 2000), 99-113. 
below), these mission activities are portrayed as closely linked to churches and in cooperation with these churches. In short, Paul's mission cannot be separated from the mission of these churches:

The Christians of Jerusalem took some responsibility for Saul (9:30, “and when the brothers learned this, they brought him down to Caesarea and sent him off to Tarsus”).

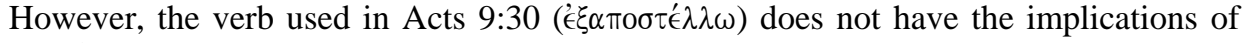
$\pi \rho \pi^{\prime} \mu \pi \omega$ which appears as a technical term in the NT for the commissioning of missionaries (see below).

Did Paul maintain some links with the churches of Damascus and/or Jerusalem during this time in Tarsus? Did he understand himself as a missionary of the churches of Damascus and/or Jerusalem? Paul's own, all too brief account in Galatians, which emphasises his independence from Jerusalem, does not mention the planting of churches (hardly to be expected, since this would not contribute to Paul's argument).

Did Barnabas know of Paul's mission activities in Syria and Cilicia and possibly in Tarsus? Did he recruit Paul's help for the newly established Gentile Christian church in Antioch for that reason? Barnabas knew that Paul was to be found in Tarsus. Luke does not mention what Paul did in Tarsus $(9: 30 ; 11: 25$ - did he stay in the city the whole time?). The references to churches in Syria and Cilicia in Acts 15:23 and 16:5 may suggest that Paul (and presumably others) had been active there (the so-called first missionary journey of Acts $13 f$ had not included these areas!). ${ }^{19}$

Paul's several journeys to Jerusalem (11:27-12:25; 15:4-33; 18:22; 21:15ff), including one longer stay in the city (11:27-12:25 - the duration of the other is not clear), also suggest Paul's continued allegiance and links with the church there. Whatever else may have attracted him to Jerusalem, these are the people he came to visit. Despite the criticism of some Christians in Jerusalem, (many?) others - including the leaders supported Paul's mission (15:4; 21:17-20). Paul even travelled there when he (rightly) anticipated trouble (Rom 15:31).

3. In Acts 11:19f Luke returns to the other Diaspora Jewish Christians who fled from Jerusalem (8:4) and specifically refers to their missionary activities: they "went about preaching the word” (8:4). They proclaimed the word to Jews in Phoenicia, Cyprus and Antioch, well beyond Jerusalem, Judea and Samaria (11:19). The results of their ministry are not mentioned.

When they came to Antioch, some of these Hellenists from Cyprus and Cyrene began to proclaim the gospel of the Lord Jesus to non-Jews also and thus started the systematic Gentile mission and church planting in a Gentile context (11:21). The first Gentile Christian church, whose origin and ministry Luke reports in some detail, was established by refugees from Jerusalem - without mention of an explicit divine or human charge to do so (cf. 8:26, 29; 10:9-23). This crossing of ethnic and/or religious boundaries occurred without the direct involvement of the apostles: in other words, the spread of the gospel was not limited to the apostles (see 8:14). As Diaspora Jews, these Hellenists were familiar with Jewish communities in the Diaspora and the necessity of adhering to Jewish identity. This might explain why, following this pattern, they established a church in Antioch. Given their background (i.e. the Diaspora), they were prepared to share the gospel in Gentile contexts.

19 While Acts knows of Paul's origin from Tarsus (9:11; 21:39; 22:3), it is interesting to note that - according to Acts and to Paul's letters - Paul never returned to Tarsus after Acts 11:26. Had he fulfilled his task as a pioneer missionary (Rom 15:18-21) there by then? 
Joseph Barnabas, who had already played a significant role in the church of Jerusalem, was of particular importance. He had introduced Saul to the church (9:26f). The church sent Barnabas, "a good man, full of the Holy Spirit and of faith" (11:24) to supervise the mission activities of some of its (former) members in Antioch. ${ }^{20}$ Barnabas was not explicitly sent by the apostles (as had been the case with Peter and John in $8: 14)$, but by the church of Jerusalem (11:22, "report of this came to the church in Jerusalem, and they sent...”). Did the church as a whole take responsibility for its members and for their mission? ${ }^{21}$

Barnabas, Saul's patron in Jerusalem (9:26-30), got Saul to join the mission work in Antioch that had been started by the Jerusalem church. Barnabas worked with Paul for a whole year in this mission and familiarised him with the traditions and mission of Jerusalem. $^{22}$

4. Christians of Jerusalem and mission. The mission of the church in Jerusalem continued through the mission of its 'daughter' in Antioch. The fact that we do not hear much of other mission activities of the Jerusalem church does not mean that these activities did not occur. However, some incidental evidence is worth nothing:

- John Mark, a Jewish Christian from Jerusalem, for some time joined the first missionnary journey (Acts 12:25; 13:13).

- The church in Jerusalem continued its interest in mission and its theological implications (although Paul would not have appreciated the attention given to him by some in the Jerusalem church): some Christians from Judea were concerned with the developments and went to Antioch with their own agenda for the inclusion of Gentile Christians (15:1). They had been informed about what happened there and felt enough responsibility to travel there. There are a number of persuasive suggestions why this concern only arose at that point in time.

- When the discussion was referred back to Jerusalem, the apostles and the elders as well as 'all the assembly' $(15: 12)$ gathered and decided on how to proceed with Gentile Christian converts, an issue that had arisen through the mission of some of its members in Antioch and elsewhere. That they gathered in this manner testifies to the interest in, and the commitment of the whole church to, matters arising from mission.

- After this council in Jerusalem, Judas and Silas, two trusted local Christians, were sent by the Jerusalem church to Antioch, together with Barnabas and Paul. They were to affirm verbally the decisions and the letter of the council (15:27; see also $15: 25,32,40)$. They were prophets from the church in Jerusalem and, through their ministry among the Gentile Christians, they "encouraged and strengthened the brothers with many words". In this way they participated in the mission of their Hellenist fellow Christians.

20 It is not clear why Barnabas from Cyprus could stay behind in Jerusalem when other Hellenists had to leave the city. Did he - as a Levite - have a special position or take a different stance toward the temple and the Law?

21 Since the apostles apparently saw their own mission directed and restricted to Israel, they might (at least in the beginning; up to Acts 12; see Gal 2:7-9), have refrained from venturing outside of Jerusalem and Judea (including Samaria). At a later stage they are active elsewhere, e.g. Acts 9:32-43.

22 See for example R Riesner, Paul's Early Period: Chronology, Mission Strategy, Theology (Grand Rapids, Cambridge UK: Eerdmans, 1998), 271f; M Öhler, Barnabas, WUNT 156 (Tübingen: Mohr Siebeck, 2002) and Schnabel, Paul the Missionary, 71-74. 
It is likely that the same Silas later joined Paul for the second missionary journey $(15: 40$; Silas also was a Roman citizen, 16:37). What Silas explained and affirmed by word of mouth in Antioch, he could also explain and affirm in the churches Paul intended to visit in Syria and Cilicia. Paul's choice of Silas as his travel companion, as well as his return to Jerusalem shows to what extent Paul linked his mission to the church in Jerusalem.

At the end of the second missionary journey Paul probably visited Jerusalem. Although the city is not mentioned, this location is suggested by the verb $\alpha \nu \alpha \beta \alpha i \nu \omega$ : "he went up [from Caesarea, where Paul had arrived] and greeted the church, and then went down to Antioch". The visit is not described in detail.

Paul's visit presumably had to do with the vow he had taken in Cenchreae (18:18). Had Paul - in addition to his purpose which shows his Jewish identity and his allegiance to the institutions of Israel - also come to report about his missionary activities (as in 14:27; 15:3f) or to clarify (further) issues which had arisen from his mission? Was the goal to deliver 'private' alms (cf. Gal 2:10; Acts 24:17) or was it related to Paul's collection for the saints in Jerusalem, an issue which was to occupy Paul significantly during his third missionary journey ${ }^{23}$

In addition to its obvious topographical meaning (going up from sea level at Caesarea to Jerusalem and then going down to Antioch), the expression 'he went up' ( $\alpha \nu \alpha \beta \dot{\alpha} \varsigma)$ could also be seen as a technical term for a pilgrimage to Jerusalem (cf. Paul's later desire to be in the city for Pentecost; 20:16; 1 Cor 16:8). CK Barrett discusses further possibilities and notes that "Johnson takes a different view. Paul went to Jerusalem for one reason only: to assert his continuing fidelity to the original apostolic community". ${ }^{24}$ Witherington writes: "Presumably Paul stayed long enough to finish his vow and report to the church in Jerusalem, as well as 'greet' them". ${ }^{25}$ It is noteworthy that, in Acts 18:22, Luke can refer to

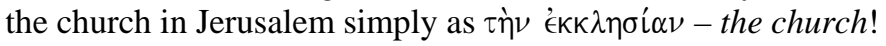

All the protagonists of the first two mission journeys in Acts were Christians with strong links to the church in Jerusalem and who had spent some time in Antioch. Their mission should be seen as the mission of the churches of Jerusalem and Antioch. The first person who was not in this category seems to have been Timothy from Lystra (16:1-3). People like Silas are often eclipsed by the Jewish Christian opponents of Paul from Jerusalem and Judea, who are specifically mentioned in Acts and in Paul's letters. ${ }^{26}$

\section{Mission of the Church in Antioch}

Prompted by the Holy Spirit, Barnabas and Saul were commissioned with fasting, prayer and the laying on of hands by the church in Antioch, which itself had been founded and nurtured by Christians from Jerusalem. As emissaries of the Antiochene church, Barnabas and Saul started what became known as the first missionary journey (13:1-3). Acts 14:26 recalls that they had been commended in Antioch to the grace of God for the work which they had to fulfil. These statements bracket the account of the journey. The activities that

23 See S McKnight, 'Collection for the Saints', in GFHawthorne, RP Martin, DG Reid (eds.), Dictionary of Paul and his Letters (Downers Grove, Leicester: IVP, 1993), 143-47.

24 A Critical and Exegetical Commentary on the Acts of the Apostles II: Introduction and Commentary on Acts $X V$-XXVIII, ICC (Edinburgh: T \& T Clark, 1998), (880f) 881.

25 Acts, 559.

261 Corinthians 9:5 suggests that upon leaving Jerusalem (presumably after Acts 12?), the remaining apostles pursued a travelling ministry which will have included mission to Jews; see Stenschke, 'Married Women'. 
take place in these brackets, are activities of the church of Antioch through its emissaries. As in Acts 11:19-26, nothing is said about the apostles.

There is also an incidental reference to the commissioning of Barnabas and Saul by the church. In Acts 14:4 and 14:14 they are called 'apostles'. ${ }^{27}$ Since neither man fulfils the criteria of Acts 1:21f for apostles, apostle should here be understood in the sense of 'envoy': "Paul and Barnabas were apostles but in a sense different from that in which Peter and John were apostles. They had been sent out (13:1-3) by the church of Antioch, to which they reported back on their return (14:26f); that is, they were apostles of a church (cf. 2 Cor

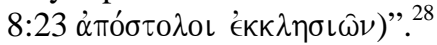

Paul and Barnabas returned to the church of Antioch: "And when they arrived and gathered the church together, they declared all that God had done with them and how he had opened a door of faith to the Gentiles” (14:27). The gathering of the church, its interest in mission, and the 'statement of accounts' that the envoys gave of their commission indicate that their mission work was embedded in the church.

During the second missionary journey Paul worked as a tentmaker to support himself (18:3) until Silas and Timothy arrived from Macedonia (perhaps with a gift from the church in Philippi?; see Phil 4:10-21). ${ }^{29}$ Nothing is said of such work during the first journey. Did the Antiochene church not only fast, pray and lay hand on its envoys (13:2f), but also finance the mission of Barnabas and Paul, just as it had supported the church in Jerusalem in Acts 11:27-30?

Paul and Barnabas ministered for a longer period of time in the church at Antioch (14:28). ${ }^{30}$ Presumably they continued their previous teaching (11:26). This they also continued after their return from Jerusalem: "But Paul and Barnabas remained in Antioch, teaching and preaching the word of the Lord, with many others also" (15:35). Paul (and others) combined the roles of pioneer missionary and teaching pastor, be it in Antioch or elsewhere.

For their second journey, the missionaries were commended to the grace of God by the Christians of Antioch (15:40). "For Luke, his [Paul's] departure with Silas took place with the commendation by the believers to the grace of the Lord, but it is increasingly the case that Paul himself takes the initiative"31 (see 15:36). Through Silas from Jerusalem, the second missionary journey is also part of the extended mission of the church in Jerusalem

27 Barrett, Acts I, 671; on the text critical problem in Acts 14:14 see pp. 678f. Barrett's conclusion is not compelling: "If after this chapter Paul is no longer described as an $\dot{\alpha} \pi$ ó $\tau 0 \lambda$ o $\varsigma$ this might be because he no longer was an apostle of the church in Antioch, or of any other; he was working on the lines described in Gal 1:1” (671f); see also Witherington, Acts, 419f. In addition to 2 Corinthians 8:23, Witherington refers to Philippians 2:25 and Didache 11:3-6.

28 For the mission of the church of Antioch, see also IH Marshall, “Who Were the Evangelists?”, in J Adna, H Kvalbein (eds.), The Mission of the Early Church to Jews and Gentiles, WUNT 127 (Tübingen: Mohr Siebeck, 2000), (251-63) 257.

29 However, Paul provides reasons other than financial need for working for his own sustenance in Corinth. For the mission of Paul and finances see the challenging study of CR Little, Mission in the Way of Paul: Biblical Mission for the Church in the Twenty-First Century, Studies in Biblical Literature 80 (New York, etc.: Peter Lang, 2005).

30 After a while "Paul and Barnabas and some of the others [as witnesses?] were appointed to go up to Jerusalem” (15:2). This suggests that Barnabas and Paul, as well as the church of Antioch (and their opponents) accepted the authority of the Jerusalem church to resolve the matter that had arisen from the mission activities of some of its former members (if this is how the Hellenists saw themselves).

31 Marshall, 'Evangelists', 257. The initiative mentioned by Marshall is Paul's desire to visit the people that had come to faith during the previous journey (15:36). In contrast to Acts 13:1-3, a special prompting by the Holy Spirit is not mentioned. 
(see above). There is no suggestion in the text that either Silas or the Jerusalem church distanced themselves from this journey when its original purpose $(15: 36 ; 16: 4 \mathrm{f})$ - for which Silas was probably chosen and might have felt particularly responsible - changed, that is, when its geographical scope changed or widened (16:6-10) or when the mission activities led to dangerous consequences - as in Philippi, Thessalonica and Corinth (16:16-40; 17:1-10; 18:1-8).

Paul (and Silas) returned via Caesarea ${ }^{32}$ and Jerusalem (see above) to Antioch (18:22). From Acts 14:27f one may conclude that Paul gave an account of his journey and continued his ministry in the Antiochene church. Paul's repeated visits to Antioch indicate his allegiance to the church there.

And "after spending some time there, Paul departed and went from one place to the next through the region of Galatia and Phrygia, strengthening all the disciples" (18:23; coworkers appear only in 19:22). At the end of this third Lukan journey, Paul did not return to Antioch because he seems to have been pressed for time (see 21:4) and planned to be in Jerusalem for Pentecost (20:16, "for he was hastening to be at Jerusalem, if possible, on the day of Pentecost" - this timing probably had to do with Paul's collection for the saints in Jerusalem, see below). Paul's arrest made further visits to Antioch impossible. Possibly Paul had planned a further visit to Antioch on his way to Rome (18:22, from Jerusalem down to Antioch; Rom 15:22-24; cf. also 2 Tim 4:13).

New churches were founded as a result of the efforts of the Antiochene church and its emissaries. Over several years the church sent its members (perhaps at a later stage more accurately 'let them go') and presumably prayed for them beyond the first commissioning (13:3). It is possible that the church also provided the means for the spread of the gospel (see above).

The mission of Paul was a mission endeavour of the (Jerusalem and) Antiochene church. $^{33}$ In Luke's account, Paul retained close ties with the churches of Jerusalem and Antioch. His mission cannot be separated from these churches. It is therefore misleading to speak of Paul's mission or the Pauline mission, without giving sufficient credit to the ecclesial embeddedness of this mission, that is, to the churches that commissioned Paul, prayed for him, financed him, provided co-workers, etc. Paul's mission was church-based, church-commissioned, church-supported in prayer, church-staffed (through the provision of co-workers, see below), church-financed and led to the founding of new churches.

Although Paul's mission was embedded in the church of Antioch, the church apparently left the concrete, practical shaping and planning of mission activities to its missionaries. The relationship between the commissioning church and her missionaries seems to have been characterised by mutual trust. This was already apparent in the first missionary journey. Following the prompting of the Holy Spirit, the missionaries themselves put the mission team together (1) and planned the route (2). Barnabas, who initially led the group, took his relative John Mark along as an attendant (14:5; although he was not among the people set apart for this task). The mission started in Cyprus, where Barnabas came from (4:36; 13:4-12). ${ }^{34}$ In other instances the route depended on guidance by the Spirit (see 16:6-10).

32 At the end of the third journey Paul visited the church in Caesarea and spent several days there. The Christians of Caesarea seem to have taken a lively interest in Paul (21:8-16). Some of them even came with Paul to Jerusalem (21:16).

33 We do not know what role the church of Damascus (and possibly the churches of Syria, Cilicia and Tarsus) had in this.

34 See D French, “Acts and the Roman Roads of Asia Minor”, in DWJ Gill, C Gempf (eds.), The Book of Acts in Its Graeco-Roman Setting, AFCS 2 (Grand Rapids: Eerdmans; Carlisle: Paternoster, 1994), 49-58. 
The freedom given to the missionaries apparently also included (in some cases):

- longer periods of ministry (3; cf. Paul's longer stays in Corinth and Ephesus; 18:11; 19:10),

- the liberty and possibility of earning their own support when and where needed or considered more appropriate for different reasons (4; 18:1-3),

- the foundation of churches (5; did Paul view the churches founded by him as 'his' churches? How did the churches understand themselves? Does the later collection for the saints in Jerusalem imply that all the churches were linked to Jerusalem?) and

- ties between the missionaries and the churches founded by them (6). In the course of time these new ties may have weakened the ties to Antioch.

Marshall's conclusion: “It would seem that, for Acts, the [Paul's] connection with Antioch is not so much broken as rather lapses under the pressure of events" 35 is too strong. Is there evidence for a 'lapse' other than the long periods of ministry away (which is to be expected from missionaries!) and the direct move to Jerusalem at the end of the third journey? This liberty given to the missionaries needs to be included in any assessment of the relationship between the missionaries and the commissioning churches.

\section{Summary}

Mission in Acts is the mission of the church. In addition to this evidence for evangelism by local churches it has become clear that mission in Acts was initiated and accomplished by individuals and churches: by churches, by individuals belonging to churches, and/or by churches through individuals. The mission activities of prominent figures such as Paul were deeply embedded in churches. This is where Paul himself, his support and co-workers came from; this is where he returned regularly, reported and ministered and where he was with some exceptions - accepted.

The role and significance of churches and/or of ordinary Christians in the spread of the gospel has been questioned and much debated recently. The discussion has focused on Paul. The subtitle of R Plummer's monograph is representative of the issues at hand: Did the Apostle Paul expect the early Christian communities to evangelize? We have seen that Acts has its own contribution to that question. This portrait needs to be combined with the Pauline evidence and other evidence for a deeper understanding of the spread of early Christianity. The role of the churches and their members in mission needs to be given more credit. However, to compare this role or to 'play it off' against the significance and contribution of individual Christians would be artificial, since the few individuals whom are known to have been active in early Christian mission did so as members of churches.

The above portrayal of the Paul of Acts challenges the notion that Paul was an isolated figure. It is more accurate to see Paul as the missionary of several early churches and as someone who worked in close co-operation with them. The ongoing significance for Paul of Jerusalem and its church and the church at Antioch needs to be considered more carefully. What influence did the churches to which Paul belonged and with whom he cooperated have on the course and nature of his mission and on his theology? What was the influence of traditions that were passed on to him in that church context or through the pattern and example set by these churches? How was Paul influenced through the people who joined him for different lengths of time or through the support, discussions and also

35 'Evangelists', 257f. 
criticism (at least by some!) which he received from these various churches? What impact did Paul's mission and the issues it raised have on these churches?

Involvement in mission was an essential task and characteristic of early Christian churches. Indeed, the portrayal of the mission of the church in Acts continues to challenge the mission of the church today. Although, historically, mission was often promoted and moved forward by individual missionaries, by monastic orders and the many mission societies (many of them necessary because churches were not fulfilling their calling!), mission primarily is and should be the mission of the church. ${ }^{36}$ Most of these individuals and institutions were closely linked to churches and engaged in mission as members of churches. Some of them were later 'adopted' by churches or denominations. Despite such developments, missiology as a discipline, and, in fact, the practice of mission, should emphasise afresh that mission is missio Dei and missio ecclesiae, the mission of the church.

For a variety of reasons, as far as the churches in my context are concerned, cross-cultural mission is no longer a given fact and task for churches. At the bottom of this development are doctrinal issues, as well as lack of certainty and conviction, limited resources, lack of interest in what happens elsewhere, and a general refusal to be involved. However, in many churches there is also a fresh commitment to local evangelistic, social, cultural and political challenges. Translocal and local mission must not be played off against each other. The inspiring challenge and cross-fertilisation of cross-cultural and intercontinental mission for the church in Europe may otherwise be lost. Moreover, the insights that missionaries such as Roland Allen discovered and developed while they were involved in mission and later applied to the challenges at home will be lost. Boundaries will no longer be crossed and our perspective will remain limited by horizons that are all too familiar. ${ }^{37}$ In fact, it would be a form of impoverishment that the churches of Europe cannot afford at this present, crucial time.

36 For the missiological significance of commissioning churches see $\mathrm{H}$ Afflerbach, Die heilsgeschichtliche Theologie Erich Sauers, STM 16, TVG (Wuppertal: Brockhaus, 2006), 344-76.

37 See the thorough treatment by H Christiansen, Missionieren wie Paulus? Roland Allens missionstheologische Rezeption des Paulus als Kritik an der neuzeitlichen Missionsbewegung, MWF NF 24 (Neuendettelsau: Erlanger Verlag für Mission und Ökumene, 2008). 